\title{
KINERJA BIAKAN MURNI RHIZOPUS OLIGOSPORUS PADA PEMBUATAN MINYAK KELAPA MURNI (VCO)
}

\author{
Irwan Hidayatulloh ${ }^{1}$, Bintang Iwhan Moehady ${ }^{1, *}$ \\ ${ }^{1}$ Politeknik Negeri Bandung, Jl. Gegerkalong Hilir, Ciwaruga, Kec. Parongpong, Kabupaten Bandung \\ Barat, Jawa Barat 40559 \\ *e-mail: bintang@polban.ac.id
}

\begin{abstract}
ABSTRAK
Pembuatan minyak kelapa murni dari santan kelapa dapat terjadi oleh perlakuan mikroorganisme yang menyebabkan pecahnya emulsi santan. Penelitian ini bertujuan untuk mendapatkan minyak kelapa dengan menggunakan biakan murni Rhizopus oligosporus dalam bentuk sel bebas pada kondisi optimum temperatur dari mikroba tersebut secara fermentasi batch. Percobaan dilakukan dengan memvariasikan jumlah biakan murni Rhizopus oligosporus. Dari penelitian ini diperoleh hasil VCO terbaik yakni pada percobaan dengan jumlah ragi biakan murni $1.350 .000 \mathrm{mikroba} / \mathrm{ml}$ pada temperatur $37^{\circ} \mathrm{C}$ yang menghasilkan produk minyak 81,80 gram. Secara analisis fisik diperoleh turbiditas 3,4 NTU serta warna, bau dan rasa yang normal, sedangkan berdasarkan hasil analisis kimia produk tersebut memiliki kadar air 0,2 \%, kadar asam lemak bebas 0,52 \%, dan bilangan penyabunan $262,968 \mathrm{mg} \mathrm{KOH} / \mathrm{g}$ lemak.
\end{abstract}

Kata kunci: Minyak kelapa murni, Rhizopus oligosporus, biakan murni.

\begin{abstract}
The production of virgin coconut oil from coconut milk can be done by microorganism treatment that causes the coconut emulsion to break. This study aims to obtain coconut oil using pure cultures of Rhizopus oligosporus in the form of free cells at optimal temperature conditions of these microbes by batch fermentation. Experiments were carried out by varying the number of pure cultures of Rhizopus oligosporus. From this research, the best VCO result was the experiment done with the amount of pure culture yeast of $1,350,000 \mathrm{microbes} / \mathrm{ml}$ at $37^{\circ} \mathrm{C}$, producing 81.80 grams of oil product. Physical analysis resulted in turbidity of 3.4 NTU and normal color, odor, and taste, whereas chemical analysis resulted in moisture content of the product of $0.2 \%$, free fatty acid content of $0.52 \%$, and saponification number of $262.968 \mathrm{mg} \mathrm{KOH} / \mathrm{g}$ fat.
\end{abstract}

Keywords: Pure coconut oil, Rhizopus oligosporus, pure culture

\section{PENDAHULUAN}

Minyak kelapa murni (virgin coconut oil) merupakan produk bernilai tinggi yang berasal dari ekstrak daging buah kelapa. Minyak kelapa murni secara alami memiliki rasa yang manis dengan kandungan $92 \%$ asam lemak jenuh yang memberikan banyak manfaat untuk kesehatan tubuh (Boemeke dkk, 2015). Kandungan asam butirat dalam minyak kelapa dapat digunakan sebagai obat untuk mencegah kanker (Dumancas dkk, 2016). Selain itu, kandungan lain seperti asam laurat memiliki khasiat sebagai antibiotik alami yang dapat membunuh bakteri, jamur dan virus. Pada beberapa penilitan menyebutkan bahwa dengan mengkonsumsi VCO dapat menurunkan resiko penyakit alzheimer (Law dkk, 2014).

Untuk meningkatkan hasil dan kualitas produk kelapa, suatu metode ekstraksi untuk menghasilkan minyak kelapa yang baik perlu menjadi perhatian khusus. Teknologi pembuatan minyak kelapa pada dasarnya terbagi dua yaitu dry method dengan bahan baku kopra dan 
wet method dengan bahan baku kelapa segar (fresh coconut) yang ditambahkan air lebih dulu (Bawalan \& Chapman, 2006; Raghavendra \& Raghavarao, 2010).

Pembuatan minyak kelapa murni (virgin coconut oil) dengan proses ekstraksi basah dapat dilakukan melalui fermentasi dengan menambahkan sejumlah mikroba ke dalam larutan santan yang kemudian diinkubasi dalam sebuah bioreactor pada suhu kamar (Handayani, 2009). Metode fermentasi ini memiliki kelebihan dan juga kekurangan. Kelebihan yang di dapatkan diantaranya minyak kelapa yang di hasilakan lebih banyak, tidak ada penambahan bahan kimia dalam ekstraksi dan energi yang di butuhkan lebih sedikit karena ekstraksi di lakukan pada suhu kamar sedangkan kekurangan untuk metode fermentasi adalah proses recovery yang terbilang rendah dan bau yang ditimbulkan dari hasil fermentasi dapat menutupi ciri khas minyak kelapa (Krishna dkk, 2009).

Penelitian tentang pembuatan minyak kelapa murni (VCO) secara fermentasi untuk mendapatkan hasil VCO baik dan ekonomis dengan menggunakan beberapa jenis mikroba yang berbeda telah diteliti, diantaranya menggunakan mikroba Lactobacillus plantarum (Satheesh \& Prasad, 2014) dan Saccharomyces cerevisiae (Andaka \& Sentani, 2016), sedangkan penelitian tentang pembuatan minyak kelapa secara fermentasi dengan menggunakan biakan murni jenis mikroba lain seperti Rhizopus oligosporus masih terbatas. Ragi tempe yang merupakan makan fermentasi khas Indonesia tentunya lebih ekonomis dan sangat mudah didaptakan di Indonesia (Kustyawati, 2012). Berdasarkan bahasan di atas, maka pada penelitian ini dilakukan studi tentang pembuatan minyak kelapa secara fermentasi batch dengan biakan murni Rhizopus oligosporus dalam bentuk sel bebas pada kondisi optimum temperatur dari mikroba tersebut.

\section{BAHAN DAN METODA}

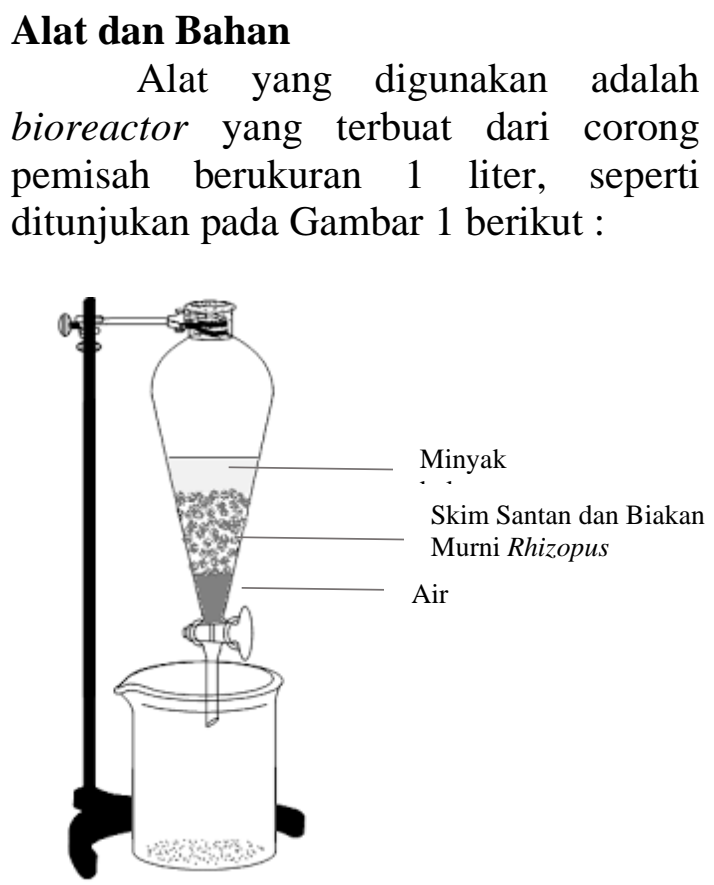

Gambar 1. Rangkaian Alat Bioreactor

Bahan yang di gunakan pada penelitian ini adalah santan kelapa dan biakan murni Rhizopus oligosporus yang diperoleh dari ITB.

\section{Prosedur Penelitian}

Penelitian ini dimulai dengan mendapatkan $1 \mathrm{~L}$ santan dari campuran parutan kelapa dan air panas dengan perbandingan 1:1. Santan dimasukan ke dalam sebuah bioreactor kemudian dicampur dengan biakan murni Rhizopus oligosporus dengan variasi sebesar $1.300 .000 \mathrm{mikroba} / \mathrm{ml} ; 1.350 .000$ mikroba/ml ; 1.750 .000 mikroba/ml ; $1.900 .000 \mathrm{mikroba} / \mathrm{ml} ; 2.200 .000$ mikroba/ml ; 2.300 .000 mikroba/ml. Fermentasi dilakukan dalam sebuah bioreactor dengan kondisi operasi seperti pada penelitan yang sudah dilakukan sebelumnya (Moehady dan Hidayatulloh, 2020) yakni pada suhu $37^{\circ} \mathrm{C}$ selama 72 
jam. Dari proses fermentasi tersebut diperoleh minyak yang kemudian dilakukan sentrifugasi selama 30 menit dengan kecepatan putaran $2500 \mathrm{rpm}$ agar didapatkan minyak yang lebih jernih. Minyak kelapa murni selanjutnya dianalisa kandungannya yang meliputi jumlah minyak yang dihasilkan (gram), Indeks Turbiditas (NTU), jumlah pengotor, kadar air, asam lemak bebas, minyak pelican dan bilangan penyabunan yang didasarkan pada Standar Nasional Indonesia (SNI ).

\section{HASIL DAN PEMBAHASAN}

Pada penelitian ini minyak kelapa murni (VCO) dihasilkan dari proses fermentasi santan dengan dengan biakan murni Rhizopus oligosporus. Dari beberapa variasi percobaan yang telah dilakukan, pada jumlah biakan murni $1.350 .000 \mathrm{mikroba} / \mathrm{ml}$ diperoleh hasil minyak kelapa murni terbaik yang sesuai dengan SNI 7381:2008 untuk VCO sebagai Tabel 1 berikut.

Tabel 1. Perbandingan Produk VCO Hasil Percobaan dengan SNI.

\begin{tabular}{ccc}
\hline Karakteristik minyak & Percobaan & SNI \\
& & N381:2008 \\
\hline Warna, bau, rasa & Normal & Normal \\
Turbiditas & 3,4 NTU, & - \\
Kadar air & $0,2 \%$ & $0.2 \%$ \\
Kadar asam lemak bebas & $0,52 \%$ & $0,2 \%$ \\
Bilangan penyabunan & 262,968 & $250-260$ \\
\hline
\end{tabular}

\section{Pengaruh Jumlah Biakan Murni Rhizopus oligosporus Terhadap Jumlah Produk}

Perbandingan yang tepat antara jumlah biakan murni yang digunakan dengan santan akan sangat berpengaruh terhadap jumlah produk yang dihasilkan. Dengan optimalnya jumlah biakan murni dan waktu fermentasi maka akan dihasilkan produk yang optimal pula. Ini terjadi karena semakin banyaknya mycellium atau jaringan-jaringan putih yang terbentuk yang menandakan semakin banyak jumlah bakteri yang bekerja untuk memutuskan ikatan antara minyak dan protein dalam emulsi santan. Minyak yang keluar kemudian dipisakan dari air, ampas dan pengotor lain (Rachmayanti dkk, 2020).

Hubungan antara pengaruh
jumlah biakan murni Rhizopus
oligosporus terhadap jumlah produk yang

dihasilkan dalam percobaan ditunjukkan pada Gambar 2. Dari Gambar 2 dapat dilihat beberapa variasi jumlah biakan murni dan pengaruhnya terhadap produk yang dihasilkan, dimana ditunjukkan semakin banyak jumlah biakan murni yang digunakan, maka semakin banyak jumlah produk yang dihasilkan.

\section{Pengaruh Jumlah Biakan Murni Rhizopus oligosporus Terhadap Warna, Bau dan Rasa Minyak}

Dari pengamatan fisik terhadap produk VCO yang dihasilkan, telah memenuhi standar mutu sesuai SNI 7381:2008 (Badan Standardisasi Nasional, 2008). VCO yang dihasilkan memiliki warna putih jernih, rasa khas minyak kelapa serta beraroma harum, tidak tengik. Aroma harum yang cukup kuat berasal dari fermentasi bakteri Rhizopus oligosporus dengan media 
santan yang menyebabkan aroma khas minyak kelapa sedikit tertutupi pada produk VCO.

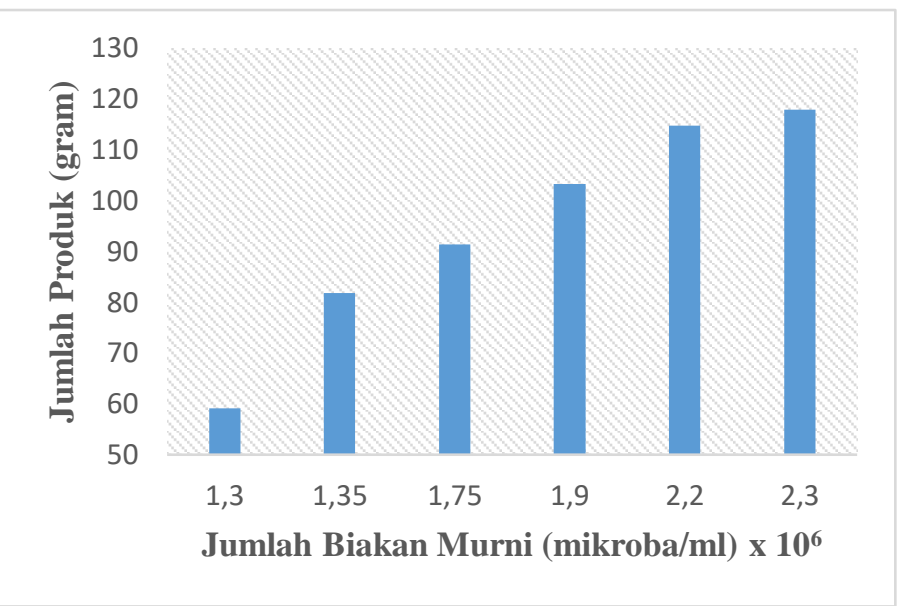

Gambar 2. Pengaruh Jumlah Biakan Murni Terhadap Jumlah Produk

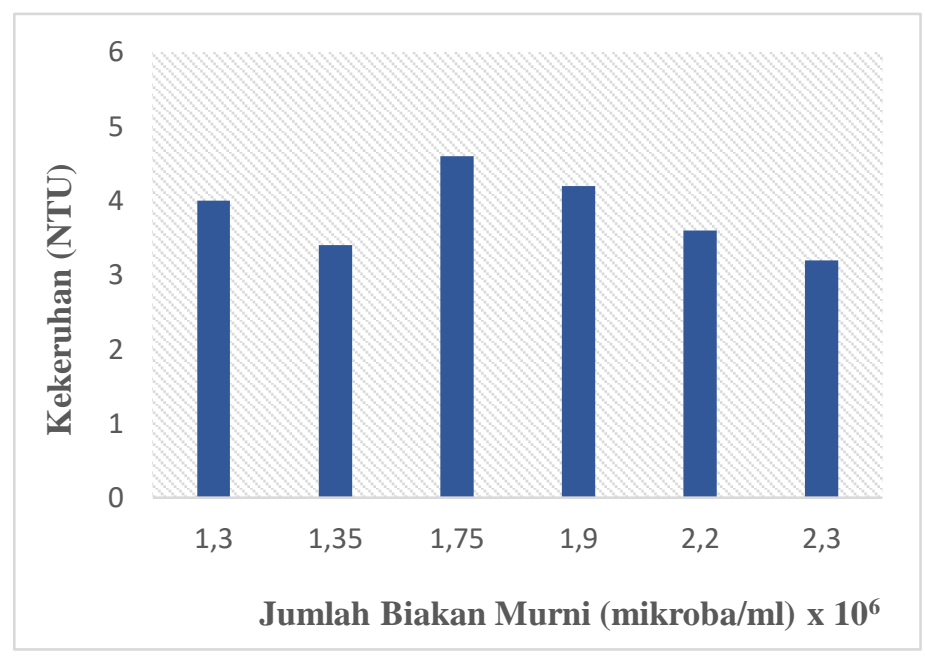

Gambar 3. Pengaruh Jumlah Biakan Murni Terhadap Turbiditas

\section{Pengaruh Jumlah Biakan Murni Rhizopus oligosporus Terhadap Turbiditas}

Kualitas dari VCO dapat dilihat secara fisik, seperti pada tingkat kejernihan produk yang dihasilkan. VCO dengan kualitas yang baik memiliki nilai turbiditas yang cukup rendah. Tingkat kejernihan VCO erat kaitannya dengan banyaknya jumlah biakan murni yang digunakan serta bagaimana proses pemisahan antara minyak dengan pengotornya. Semakin banyak jumlah biakan murni maka semakin banyak protein dan ampas yang diperoleh dari hasil pemecahan emulsi santan sehingga akan menyebabkan tingginya nilai turbiditas. Selain itu semakin banyak pengotor atau ampas maka akan semakin sulit proses pemisahan dilakukan sehingga dimungkinkan semakin banyak pula pengotor yang masih terbawa pada minyak. Gambar 3 dari hasil percobaan dapat dilihat beberapa variasi jumlah biakan murni dan pengaruhnya terhadap turbiditas, yakni menunjukkan nilai 
turbiditas yang berfluktuasi. Hal ini dikarenakan minyak kelapa dipanaskan terlebih dahulu pada suhu antara $60-80^{\circ} \mathrm{C}$ untuk memecah kembali emulsi santan (Krishna dkk., 2009). Minyak dengan pemanasan yang rendah akan terlihat lebih keruh, sedangkan minyak dengan pemanasan yang tinggi akan terlihat lebih jernih, sehingga akan mempengaruhi nilai turbiditasnya.

\section{Pengaruh Jumlah Biakan Murni Rhizopus oligosporus Terhadap Kadar Air}

Kadar air adalah jumlah bahan yang menguap pada pemanasan dengan suhu dan waktu tertentu. Pengaruh kadar air dalam minyak yaitu jika dalam jumlah yang banyak dapat menyebabkan bau tengik pada minyak. Nilai kadar air dalam minyak umumnya dipengaruhi oleh proses pemisahan dan pemanasan.

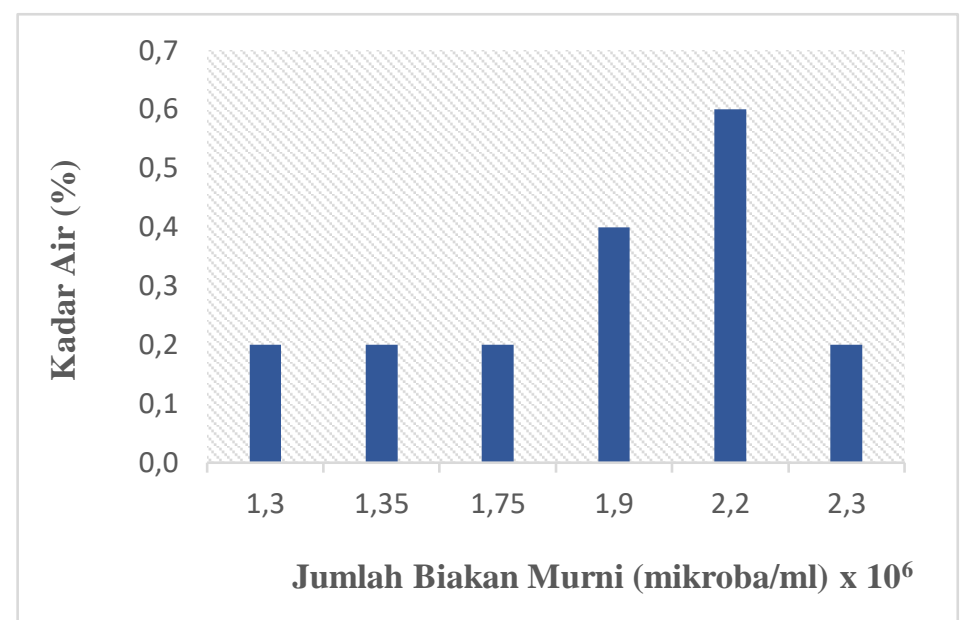

Gambar 4. Pengaruh Jumlah Biakan Murni Terhadap Kadar Air

Dari Gambar 4 dapat diketahui pada beberapa variasi percobaan yakni pada variasi jumlah biakan murni $1,9.10^{6}$ dan $2,2.10^{6} \mathrm{mikroba} / \mathrm{ml}$, produk yang dihasilkan masih memiliki nilai kadar air yang cukup tinggi yakni 0,4 dan $0,6 \%$. Hal ini dikarenakan masih ada cukup banyak kandungan air yang tidak ikut terbuang selama proses pemisahan antara air dengan minyak dan protein. Selain itu tidak stabilnya temperatur selama proses pemanasan juga menyebkan tingginya kadar air akibat proses penguapan moisture air yang kurang optimal. Berdasarkan Standar Nasional Indonesia (SNI) 7381:2008 nilai maksimum kadar air dalam minyak kelapa yang diperbolehkan adalah $0,5 \%$.

Pengaruh Jumlah Biakan Murni Rhizopus oligosporus Terhadap Kadar Asam lemak bebas
Asam lemak bebas (Free Fatty Acids) adalah turunan trigliserida (asam lemak dan gliserol). Kadar asam lemak bebas menunjukkan hasil dekomposisi trigliserida yang disebabkan oleh pengaruh bakteri. Selama proses hidrolisa dan enzimatik pada saat fermentasi, asam lemak yang berukuran besar akan diuraikan menjadi asam-asam lemak yang berukuran lebih kecil. Asam laurat merupakan asam lemak bebas yang terbesar komposisinya dalam minyak kelapa, umumnya nilai kadar asam lemak bebas merujuk pada kandungan asam laurat di dalamnya. Semakin banyak kadar asam lemak bebas akan memyebabkan timbulnya bau tengik pada minyak kelapa. Dari data percobaan pada Gambar 5 diketahui bahwa pada percobaan semakin tinggi jumlah biakan murni yang diberikan maka semakin 
tinggi kadar asam lemak bebasnya. Nilai kadar asam lemak bebas tersebut berkurang pada variasi jumlah biakan murni 2.2.10 $-2,3 \cdot 10^{6} \mathrm{mikroba} / \mathrm{ml}$. Hal ini disebabkan pada proses pemanasan mengakibatkan denaturasi minyak yang dapat menurunkan kadar asam lemak bebasnya. Pada dasarnya kadar asam lemak bebas yang tinggi tidaklah dihaarpkan karena dapat menimbulkan bau tengik pada produk VCO.

Berdasarkan standar nasional Indonesia (SNI) 7381:2008 kadar asam lemak bebas dalam minyak kelapa murni tidak lebih $5 \%$. Dari data percobaan semua produk minyak yang dihasilkan memilik kadar asam lemak bebas yang sesuai dengan standar. Meskipun pada beberapa variasi percobaan terdapak penyimpangan dari kecenderungan meningkatnya nilai kadar asam lemak bebas seiring dengan bertambahnya jumlah biakan murni tidak berarti minyak yang dihasilkan kualitasnya di bawah standar, selama kadar asam lemak bebasnya berada pada rentang yang sudah ditentukan.

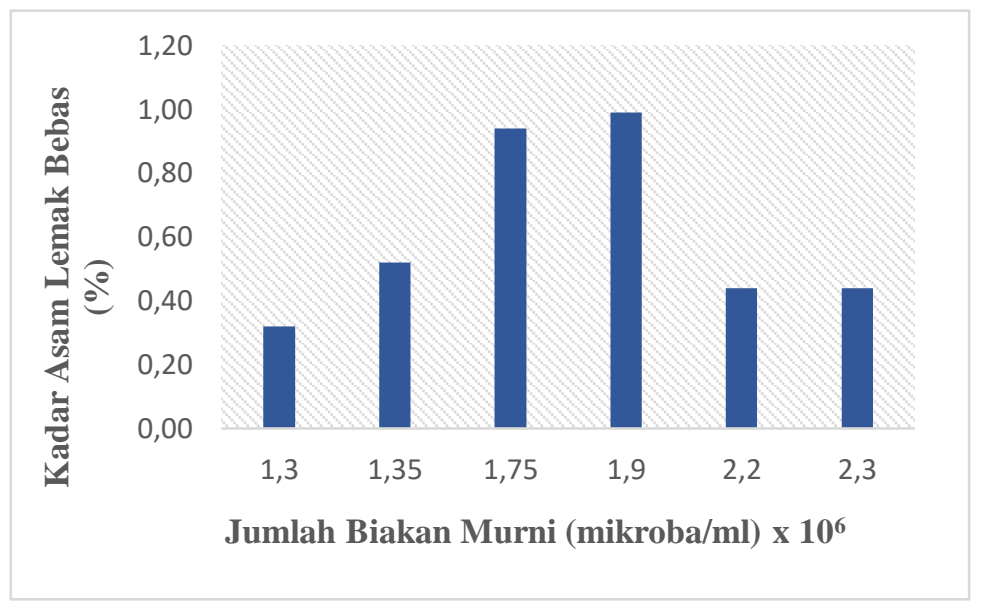

Gambar 5. Pengaruh Jumlah Biakan Murni Terhadap Kadar Lemak Bebas

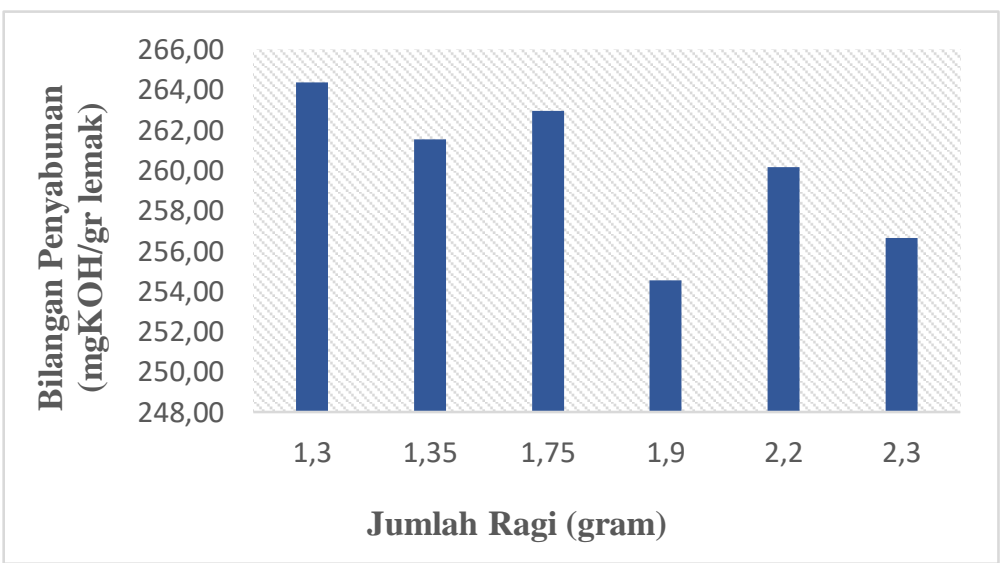

Gambar 6. Pengaruh Jumlah Biakan Murni Terhadap Bilangan Penyabunan

\section{Pengaruh Jumlah Biakan Murni Rhizopus oligosporus Terhadap Bilangan Penyabunan}

Bilangan penyabunan adalah jumlah berat $\mathrm{KOH}(\mathrm{mg})$ yang diperlukan untuk menyabunkan 1 gram lemak. Bilangan penyabunan berbanding 
terbalik dengan berat molekul dari asam lemak dan digunakan sebagai nilai pembanding yang mengindikasikan adanya asam lemak di dalam minyak. Bilangan penyabunan menjadi suatu ukuran kualitas untuk senyawa asamasam lemak yang ada pada minyak.

Berdasakan Standar Nasional Indonesia rentang nilai untuk bilangan penyabunan pada produk minyak kelapa adalah 255 - $265 \mathrm{mg} \mathrm{KOH/g} \mathrm{lemak.} \mathrm{Jika}$ bilangan penyabunan masuk ked alam range tersebut, maka dapat dikategorikan minyak tersebut baik. Dari data percobaan pada Gambar 6 ada beberapa produk dengan bilangan penyabunan yang berada di luar standar, yaitu pada variasi jumlah biakan murni $1,9.10^{6}$ mikroba/ml.

\section{KESIMPULAN}

Pada percobaan untuk variasi jumlah biakan murni 1.350 .000 mikroba/ml pada kondisi suhu optimal 37 ${ }^{\circ} \mathrm{C}$ diperoleh produk minyak kelapa murni yang paling optimal sesuai dengan standar nasional Indonesa. Diperoleh minyak kelapa murni sebanyak 81,80 gram. Dari analisa fisik dan kimia didapatkan nilai turbiditas sebesar 3,4 NTU, kadar air 0,2\%, kadar asam lemak bebas $0,52 \%$, bilangan penyabunan $262,968 \mathrm{mg} \mathrm{KOH} / \mathrm{g}$ lemak serta VCO memiliki warna, bau dan rasa yang normal minyak kelapa.

\section{DAFTAR PUSTAKA}

Andaka, G., \& Sentani, A. (2016). Pengambilan Minyak Kelapa Dengan Metode Fermentasi Menggunakan Ragi Roti. Jurnal Teknik Kimia, 10(2), 65-70.

Badan Standardisasi Nasional. (2008). SNI 7381 - Minyak Kelapa Virgin
( $V C O)$

Bawalan, D., \& Chapman, K. (2006). Virgin Coconut Oil. FAO Regional Office.

Boemeke, L., Marcadenti, A., Busnello, F. M., \& Gottschall, C. B. A. (2015). Effects of Coconut Oil on Human Health. Open Journal of Endocrine and Metabolic Diseases, 05(07), 84-87.

Dumancas, G. G., Kasi Viswanath, L. C., de Leon, A. R., Ramasahayam, S., Maples, R., Koralege, R. H., Perera, U. D. N., Langford, J., Shakir, A., \& Castles, S. (2016). Health benefits of virgin coconut oil. In Vegetable Oil: Properties, Uses and Benefits (Issue March).

Handayani, R. (2009). Extraction of Coconut Oil (Cocos nucifera L.) through Fermentation System. Biodiversitas, Journal of Biological Diversity, 10(3), 151-157.

Krishna, G., Raj, G., Bhatnagar, A., Kumar, P., \& Chandrashekar, P. (2009). Coconut Oil: Chemistry , Production and Its Coconut Oil: Chemistry, Production and Its Applications -. Indian Coconut Journal, July.

Kustyawati, M. E. (2012). Kajian Peran Yeast dalam Pembuatan Tempe. Agritech: Jurnal Fakultas Teknologi Pertanian UGM, 29(2).

Law, K. S., Azman, N., Omar, E. A., Musa, M. Y., Yusoff, N. M., Sulaiman, S. A., \& Hussain, N. H. N. (2014). The effects of virgin coconut oil (VCO) as supplementation on quality of life (QOL) among breast cancer patients. Lipids in Health and Disease, 13(1), 1-7.

Moehady, B. I., \& Hidayatulloh, I. (2020). Proses Pembuatan Minyak Kelapa Murni dengan Menggunakan Rhizopus Oligosporus. Metana, 16(1), 11-18. 
Rachmayanti, I. R., Firdaus, R. I., Wahyusi, K. N., Studi, P., Kimia, T., Teknik, F., Raya, J., Madya, R., \& Anyar, G. (2020). Menjadi Virgin Coconut Oil Dengan Katalis. Journal of Chemical and Process Engineering, 01(01), 46-50.

Raghavendra, S. N., \& Raghavarao, K. S. M. S. (2010). Effect of different treatments for the destabilization of coconut milk emulsion. Journal of Food Engineering, 97(3), 341-347. Satheesh, N., \& Prasad, N. B. L. (2014). Production of virgin coconut oil by induced fermentation with Lactobacillus plantarum NDRI strain 184. Croatian Journal of Food Technology, Biotechnology and Nutrition, 9(1-2), 37-42. 